\title{
Status of Cassava Cultivation in Jaffna Peninsula and Detection of Cassava Mosaic Disease Causing Agent
}

\author{
C J Emmanuel*, A Inthuja, A Keshiga \\ Department of Botany, Faculty of Science, University of Jaffna, Jaffna, JA 40000, Sri Lanka \\ *Email: jeyaseelan.ec@univ.jfn.ac.lk
}

\begin{abstract}
Cassava is one of the well-known vegetable crops throughout the world and the starchy tubers are used to prepare variety of food items. In Jaffna peninsula, cassava cultivation has been threatened by a disease which commonly caused by a plant virus called cassava mosaic virus. In the present study a survey was carried out to find out current knowledge and experience of farmers about cassava cultivation and cassava mosaic disease. The total DNA isolated from the infected plants was subjected to polymerase chain reaction with begomovirus specific primers to confirm the causative agent of the disease. Furthermore, controlled field experiments were carried out to confirm yield loss in different growth conditions. The survey revealed several aspects of cassava cultivation in Jaffna peninsula. In last five years the cassava crops had been continuously affected by cassava mosaic disease and that was the major factor for the reduced yield in cassava cultivation. Many of the farmers did not aware about cassava mosaic disease and effective disease management. Repeated cultivation of susceptible varieties and using infected stem-cuttings are the major reasons for the wide spread of the disease. Polymerase chain reactions have confirmed presence of begomovirus in symptomatic plants. Field experiments have revealed the spread of the pathogen through infected stem-cuttings and whitefly vectors, and confirmed the yield loss. In conclusion, cassava cultivation has been threatened by cassava mosaic disease in Jaffna peninsula, and there is an urgent need to give proper guidance to farmers to manage the disease.
\end{abstract}

Keywords - Cassava, Begomovirus, Jaffna, Mosaic disease

\section{INTRODUCTION}

Cassava (Manihot esculenta Crantz) tuber (also known as 'Maravalli' in tamil and 'Maniok' in Sinhala) has been used as one of the important agricultural food product in many developing countries in Africa, Latin America and Asia (De Bruyn et al., 2012). It is being as a staple food in several African countries due to the high carbohydrate content in tubers. Tender leaves contain up to $25 \%$ protein, iron, calcium and vitamins (Latif and Müller, 2015), and it can be used as animal feed (Ravindran 1993; Ng and Wee 1989; Madalla et al., 2016). The demand for cassava is growing largely because of the increasing demand for food production, animal feed, biofuels and multiple uses of starch.

Cassava was introduced to Sri Lanka during the Dutch period. Since then cassava stands out in Sri Lanka as the most important source of energy for the calorie deficient lowincome population. The plant is mainly cultivated in wet, intermediate and dry zones in Sri Lanka and the cultivation was in peak between the years 1970 and 1980 (Bandara and Sikurajapathy, 1992). Later on, however, the production was reduced by the factors such as diseases in cassava and successful development of potato cultivation. Although primary purpose of the cultivation of cassava is for local consumption, a significant quantity has been exported to international markets as different forms (Harischandra et al., 2005). Northern Province of Sri Lanka has a long history on cassava cultivation. Cassava fed lots of people during the civil war and still it is being one of the major vegetable crops in this region.
Cassava cultivation is affected by several pests and diseases (Graziosi et al., 2016). The cassava mosaic disease (CMD) is one of the major threats to cassava cultivation in many countries (Alabi et al., 2011; Minato et al., 2019) and several researches are being conducted to control the disease (Thresh and Cooter 2005; Maruthi et al., 2019). In several countries $\mathrm{CMD}$ is the major limiting factor of cassava production, and causing 25-95\% yield-loss (Legg et al., 2005). In Sri Lanka this disease is reported to be caused by two begomoviruses namely, Sri Lankan cassava mosaic virus and an isolate of Indian cassava mosaic virus (Salim and Bandumala, 2001; Saunders et al., 2002). Prasangika et al. (2008) reported that out of eleven germplasms of cassava, recommended and released by Department of Agriculture, Sri Lanka, only the germplasms $\mathrm{WA} / \mathrm{KK} / 10$ and $555 / \mathrm{KK} / 2$ were highly resistant to CMD infection.

In last five years, many of the cassava fields in Jaffna peninsula have been severely affected by CMD than earlier. However, it was not considered as a serious issue by the farmers and relevant stakeholders, and poor efforts were made to study and manage the disease. The present study aimed to understand the status of cassava cultivation in Jaffna peninsula and to confirm the causative agent of the disease by using virus specific primers, and yield losses in plants affected by CMD. To understand the present status of cassava cultivation in Jaffna peninsula, a survey was conducted with following objectives; find out the interest in cassava cultivation among the farmers, list down the constrains faced by farmers, understand their knowledge on CMD, find out 
possible alternative hosts for CMD causing virus and realize the pesticides and fertilizer application in cassava cultivation.

\section{MATERIALS AND METHODS}

\section{Survey on present status of cassava mosaic disease in} Jaffna peninsula

A questionnaire was prepared with queries related to cassava cultivation and CMD. Field visits were made to cassava farms in three different regions in Jaffna peninsula, namely, Valikaamam, Thenmaradchi and Vadamaradchi. Meetings were arranged with farmers individually and obtained information for questionnaires from randomly selected 82 farmers. The results were analysed using statistical software SPSS (version 21.0).

\section{Experiment to quantify yield losses due to CMD}

Both virus free and virus infected (confirmed by virus specific primers in PCR) stem cuttings of cassava, were grown in insect proof net house and open experimental garden of Department of Botany, Faculty of Science University of Jaffna. In each case 10 replicate plants were maintained. The cultivation was started in September, 2016, and after ten months the yield was measured.

\section{Detection of CMD causing agent based on polymerase chain reaction $(\mathrm{PCR})$}

\section{Sample collection and storage}

Cassava leaves with CMD symptoms were collected from seven different villages in Jaffna peninsula, namely Uduvil, Kopay, Thirunelvely, Elalai, Arali, Karaveddy and Vempirai, where cassava is cultivated in large extent. In each village, samples were collected from two different farms. Sampling was done in June 2016. All the leaf samples were packed in freezer bags and stored at $-20{ }^{\circ} \mathrm{C}$.

\section{Total genomic DNA extraction from leaf samples}

\section{Optimization of DNA extraction}

In order to find out a cost effective method the DNA was extracted in different methods. Each of these methods was repeated three times.

Method 1: Tissue sample (100 mg) was ground with liquid nitrogen in pre-chilled mortar and pestle. Total DNA of each sample was extracted by using two different methods: Cetyl trimethyl ammonium bromide (CTAB) DNA extraction method (Doyle and Doyle, 1987) or commercially available DNeasy plant mini kit (Qiagen, Germany).

Method 2: Tissue samples (100 mg) were measured and ground in two different methods: the tissue samples were ground in liquid nitrogen or in CTAB extraction buffer. Subsequently total DNA was extracted by CTAB method (Doyle and Doyle, 1987).

Quality and quantity of extracted total DNAs were measured in NanoDrop spectrophotometer (ND-2000, Thermo Scientific, USA). DNA quantity was determined at $260 \mathrm{~nm}$ absorbance. Quality was determined based on A260/280 and A260/230 ratios.

\section{DNA extraction from test samples}

Based on the results obtained in optimization of DNA extraction, leaf samples ground in CTAB extraction buffer and subsequent DNA extraction using CTAB method was considered as an appropriate cost effective method, and used for DNA extraction from test samples.

\section{Detection of causative agent based on PCR}

DNA extracts of cassava leaves collected from different regions were subjected to PCR by using primers specific to a part of DNA-A of begomovirus. Theses primers were originally designed by Deng et al. (1994) and it amplifies partial nucleotides sequence (520 nucleotides) of coat protein. Amplified products were electrophoresed on $1.5 \%$ agarose gel and visualized under gel documentation system.

\section{RESULTS AND DISCUSSION}

In the fields, it was clearly noticed that the cassava plants had symptoms that characteristic to CMD as described in previous studies (Ogbe et al., 2003; Minato et al., 2019). A range of symptoms were noticed; some plants had a mild irregular yellow patches in their mature leaves, in some other plants severer mosaic symptoms were noticed mainly in young leaf, young leaves of certain plants showed leaf puckering in addition to mosaic (Figure 1). The infected young plants showed stunted growth and highly distorted leaves, and they failed to produce tubers.

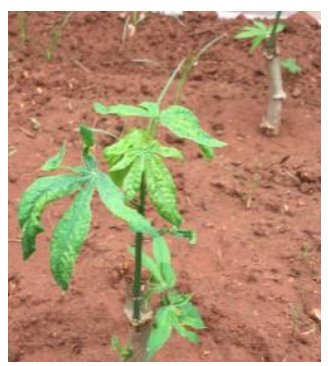

(a)

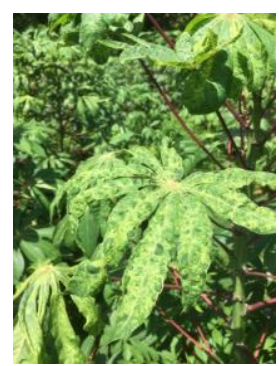

(b)
Figure 1: Symptoms of cassava mosaic disease. (a) young plant with symptoms; (b) mature leaf with mosaic and puckering symptom.

Even though symptoms may provide significant contribution in the identification of a disease, it cannot be a sole method to confirm the causative agent of the disease, because a particular symptom can be caused by different biotic or abiotic agents. In addition, symptoms develop in the mid or late stage of infection process that will not help to early detection of plant disease (Fang and Ramasamy 2015). Due to these reasons, in the present study, pathogen specific DNA amplification technique was used to detect the causative agent in addition to the symptomatology.

For a successful amplification of target DNA in PCR and for downstream applications such as cloning and sequencing good quality of DNA is essential. In the present study, different DNA extraction methods were compared in order to select a 
cost effective and simple method to extract total DNA from cassava leaves with CMD symptoms. The quantity and quality of extracted DNA using CTAB method was relatively similar or enhanced than the commercial kit (Table 1). Similarly, the way preparing samples at the initial extraction step was compared, and the result showed that the quantity and quality of extracted DNA by grinding the tissues directly in extraction buffer did not greatly vary with grinding in liquid nitrogen (Table 2). Less expensive and simple extraction protocols are very useful to researchers in developing countries like Sri Lanka. In the present study, comparison of different DNA extraction methods showed that without using hazardous liquid nitrogen and expensive commercial kits, simple grinding in warm CTAB extraction buffer and subsequent extraction with less expensive $\mathrm{CTAB}$ extraction method is equally applicable to detect CMD causing agent.

The PCR amplification of the extracted DNA with begomovirus specific primers yielded bright bands in gel electrophoresis between $500-600$ bp markers (Figure 2). This confirms that the samples having begomovirus. The primer pair and the amplification conditions used in the PCR reaction was widely used in the identification of various begomovirus pathogens in infected crop plants in Sri Lanka and other countries (Huang et al., 2006; Samarakoon et al., 2012; Bandaranayake et al., 2014).

Table 1: Concentration and quality of DNA extracted by modified CTAB method and using DNeasy plant mini kit

\begin{tabular}{|c|c|c|c|c|}
\hline \multirow[t]{2}{*}{ Leaf samples } & \multirow{2}{*}{$\begin{array}{c}\text { DNA } \\
\text { extraction } \\
\text { method }\end{array}$} & \multirow{2}{*}{$\begin{array}{c}\text { DNA } \\
\text { concentration } \\
(\mathrm{ng} / \mu \mathrm{l})\end{array}$} & \multicolumn{2}{|c|}{ Quality of DNA } \\
\hline & & & $\begin{array}{c}\text { At } \\
260 / 280 \\
\text { nm ratio }\end{array}$ & $\begin{array}{c}\text { At } \\
260 / 230 \\
\text { nm ratio }\end{array}$ \\
\hline \multirow[t]{2}{*}{ Replicate 1} & $\begin{array}{l}\text { DNeasy } \\
\text { plant kit }\end{array}$ & 339.0 & 1.82 & 1.76 \\
\hline & $\begin{array}{l}\text { Modified } \\
\text { CTAB }\end{array}$ & 319.6 & 1.92 & 1.73 \\
\hline \multirow[t]{2}{*}{ Replicate 2} & $\begin{array}{l}\text { DNeasy } \\
\text { plant kit }\end{array}$ & 300.6 & 1.82 & 1.93 \\
\hline & $\begin{array}{l}\text { Modified } \\
\text { CTAB }\end{array}$ & 568.1 & 1.89 & 1.71 \\
\hline \multirow[t]{2}{*}{ Replicate 3} & $\begin{array}{l}\text { DNeasy } \\
\text { plant kit }\end{array}$ & 317.4 & 1.80 & 1.81 \\
\hline & $\begin{array}{l}\text { Modified } \\
\text { CTAB }\end{array}$ & 996.0 & 1.85 & 1.73 \\
\hline
\end{tabular}

Table 2: Concentration and quality of DNA extracted by two different initial tissue lysis methods

\begin{tabular}{|c|c|c|c|c|}
\hline \multirow[b]{2}{*}{ Leaf samples } & \multirow[b]{2}{*}{$\begin{array}{l}\text { Plant tissue } \\
\text { lysing method }\end{array}$} & \multirow{2}{*}{$\begin{array}{c}\text { DNA } \\
\text { concentration } \\
(\mathrm{ng} / \mu \mathrm{l})\end{array}$} & \multicolumn{2}{|c|}{ Quality of DNA } \\
\hline & & & $\begin{array}{c}\text { At } \\
260 / 280 \\
\text { nm ratio }\end{array}$ & $\begin{array}{c}\text { At } \\
260 / 230 \\
\text { nm ratio }\end{array}$ \\
\hline \multirow[t]{2}{*}{ Replicate 1} & $\begin{array}{l}\text { Liquid } \\
\text { nitrogen }\end{array}$ & 279.8 & 1.86 & 1.70 \\
\hline & $\begin{array}{l}\text { extraction } \\
\text { buffer }\end{array}$ & 283.2 & 1.84 & 1.98 \\
\hline \multirow[t]{2}{*}{ Replicate 2} & $\begin{array}{l}\text { Liquid } \\
\text { nitrogen }\end{array}$ & 215.8 & 1.91 & 1.77 \\
\hline & $\begin{array}{l}\text { extraction } \\
\text { buffer }\end{array}$ & 177.1 & 1.86 & 1.88 \\
\hline \multirow[t]{2}{*}{ Replicate 3} & $\begin{array}{l}\text { Liquid } \\
\text { nitrogen }\end{array}$ & 232.9 & 1.75 & 1.71 \\
\hline & $\begin{array}{l}\text { extraction } \\
\text { buffer }\end{array}$ & 238.3 & 1.84 & 1.76 \\
\hline
\end{tabular}

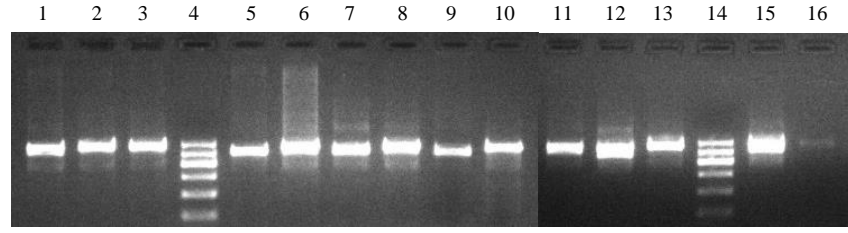

Figure 2: PCR products of DNA extracted from leaf tissues with symptoms CMD. Segment of DNA-A amplified with specific primers, expected product size is about 520 bp. Samples were collected from seven different regions in Jaffna Peninsula; 1,2- Uduvil; 3, 5- Kopay; 6, 7- Thirunelvely; 8, 9- Elalai; 10, 11- Arali; 12, 13Karaveddy and 15, 16- Vempirai; 4, 14-100bp ladder (GelPilot Wide Range Ladder, Qiagen).

The survey on status of cassava cultivation in Jaffna peninsula revealed several interesting aspects. The majority of the farmers involved in cassava cultivation had less experience in cassava farming; about $45 \%$ of farmers had less than five years of experience (Figure 3). While new farmers were more interested to grow cassava, farmers with many years of experience were not much involved in cassava farming. It is necessary to encourage the new farmers to continue their cassava farming for continuous cassava production. On the other side it is necessary to find out reason for declining of farmers' interest.

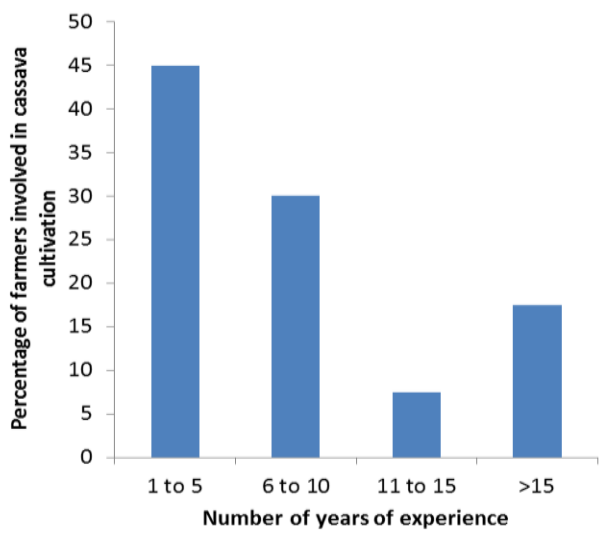

Figure 3: Years of experience of farmers in cassava cultivation.

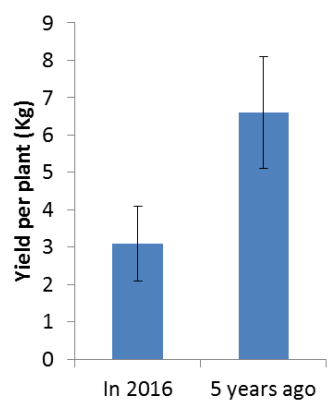

Figure 4: Obtained average yield per cassava plant in year 2016 and five years earlier.

The major complain to avoid cassava cultivation was reduction in yield. According to farmers' experience the average yield per plant reduced by $3.5 \mathrm{Kg}$ in last five years (Figure 4). There are four major reasons were 
suggested by farmers for the reduction in yield. About $74 \%$ of farmers stated that a disease with mosaic and puckering leaf symptoms was the major factor for the yield reduction. The rest of the farmers mentioned adverse environmental conditions, mealybugs or burrowing animals are the major threat to cassava cultivation and yield lost (Figure 5). Even though the famers were able to describe the symptoms of CMD, many of them (72\%) did not know about the causative agent and disease management practices related to CMD. It is clear that the farmers need awareness on CMD and its management.

Application of soil fertilizer has been a practice to increase the size and weight of cassava tubers in Jaffna peninsula. Data were collected from $56 \%$ of farmers on fertilizer application and $23 \%$ of them stated that inorganic chemicals, such as urea and potassium, were used to increase the size of tubers, and the rest of them applied organic manure. Potassium is one of the nutrients most absorbed by cassava; it acts on the synthesis and starch accumulation in the storage roots. In an experiment conducted by Fernandes et al. (2017), application of potassium increased the yield of storage roots and starch from 36-49\%, however, it differentially altered the accumulation of other elements such as $\mathrm{Ca}, \mathrm{Mg}, \mathrm{N}, \mathrm{P}, \mathrm{Mn}$ and $\mathrm{Zn}$. But in general, application of organic manure has many advantages such as increasing physical properties of soil, water holding capacity and organic carbon content apart from that supplying essential nutrients (Santhi and Selvakuari, 2000; Amanullah et al., 2007).

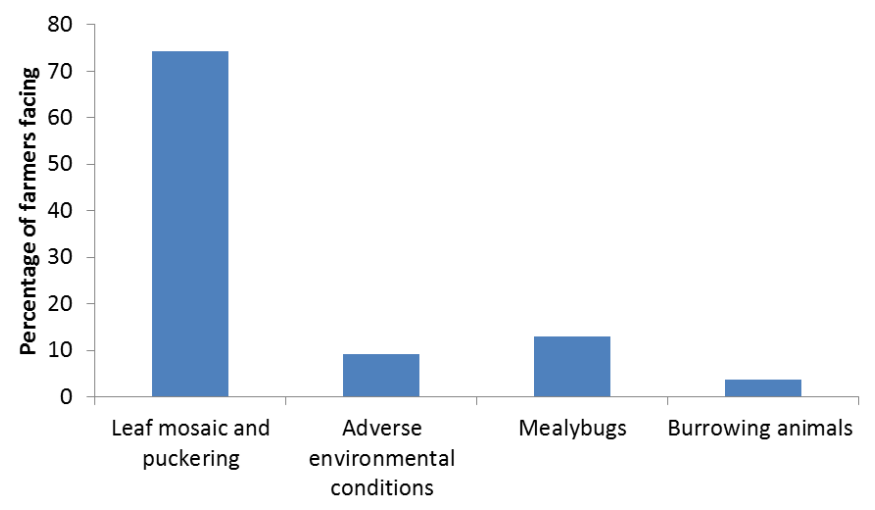

Figure 5: Factors responsible for yield reduction in cassava cultivation

Relatively larger number $(87 \%)$ of farmers practiced crop rotation in the cassava growing field with okra, onion, carrot and chilli as most frequently used crop (Figure 6). Yet, the crops, such as, okra, chilli etc. are host for several viruses and whiteflies. Viruses may have wide host range with several alternative hosts. In addition, whitefly is the major vector of several begomovirus species (Jesús Navas-Castillo et al., 2011). Therefore, the crop rotation may not effectively reduce the disease incidence in the field.

In Sri Lanka, several cultivars of cassava are being used for the cultivation (Prasangika et al., 2008). However, In Jaffna peninsula farmers are not much aware about this and they use same variety for many years. Generally, they use the stem cuttings of cassava from previous season, for propagation. In the survey it was clearly noticed that the farmers are not aware that the causative agent is disseminated through stem cuttings. Due to the continuous re-culturing of infected stem cuttings, it leads to an epidemic stage for the CMD in Jaffna peninsula. Except two farms, in Kopai (Valikamam) and Vempirai (Thenmaratchi), cassava plants were completely affected by CMD with visible symptoms in all other fields, visited in this study. Therefore, it is necessary to explain the problems associated with using infected stem cuttings, and need to propagate and provide disease free propagules to the farmers. Department of agriculture and research centres could play an active role in this aspect.

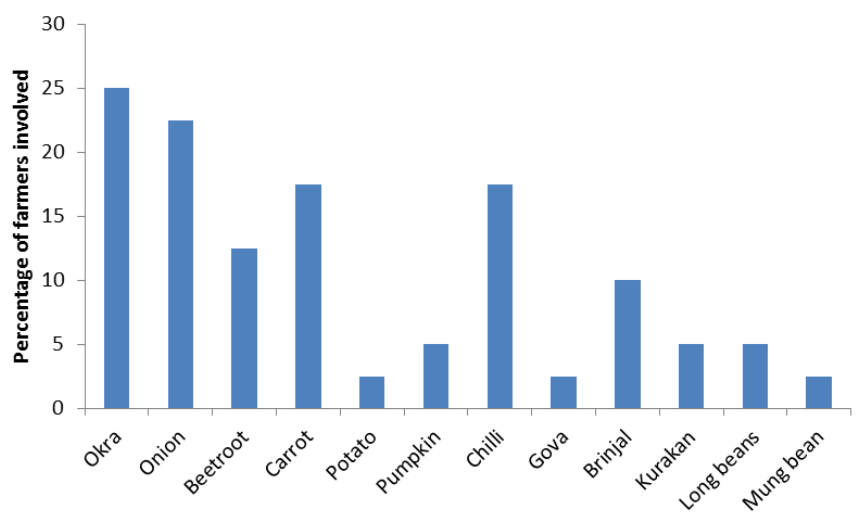

Figure 6: Types of off-season crops, cultivated in cassava fields

As per the results, there was a clear observation of $100 \%$ of disease incidence in plants grown from stem-cuttings of infected plants, and the yield was reduced by $2 \mathrm{Kg}$ to $5 \mathrm{Kg}$ (Table 3). The stem-cuttings of healthy plants were free from disease in insect-proof cage, but when they were grown in open field they showed about $20 \%$ disease incidence. This could be due to the virus transmission by whiteflies, because the plants growing in open environment had been infected by whiteflies. However, the presence of virus in those whiteflies was not confirmed in this study.

Table 3: Disease incidence and yield in cassava plants grown in different conditions

\begin{tabular}{llcc}
\hline $\begin{array}{c}\text { Growth } \\
\text { conditions }\end{array}$ & Stem cutting & $\begin{array}{c}\text { Disease } \\
\text { incidence (\%) }\end{array}$ & Yield (Kg/plant) \\
\hline Open field & Disease free & 20 & 6.5 \\
& Infected & 100 & 4.3 \\
Insect proof & Disease free & 0 & 8.2 \\
cage & Infected & 100 & 3.8 \\
\hline
\end{tabular}

Application of pesticides to cassava crops is not common practice in Jaffna peninsula. However, in recent years farmers (43\% of famers) have started to apply pesticides to manage $\mathrm{CMD}$, mainly in young plants. These pesticides are mainly targeting whiteflies. However, it is not effective for the stem cuttings obtained from an infected plant. 


\section{CONCLUSION}

The cassava cultivation in Jaffna peninsula has been severely affected by cassava mosaic disease caused by begomovirus species. Farmers have inadequate knowledge on this disease and causative agent. Introduction of resistant varieties, development of eco-friendly disease management practices and enhancing the knowledge of farmers, are urgent requirements to eradicate CMD from Jaffna peninsula.

\section{REFERENCES}

Alabi, O. J., Kumar, P. L and Naidu, R. A (2011). Cassava mosaic disease: A curse to food security in Sub-Saharan Africa. Online. APSnet Features. doi:10.1094/APSnetFeature2011-0701.

Amanullah, M. M, Vaiyapuri, K., Sathyamoorthi, K., Pazhanivelan, S and Alagesan, A (2007). Nutrient uptake, tuber yield of cassava (Manihot esculenta Crantz.) and soil fertility as influenced by organic manures. Journal of Agronomy 6, 183-187.

Bandara, W. M. S. M and Sikurajapathy, M (1992). Recent progress in cassava varietal and agronomy research in Sri Lanka, pp.96-105. In: Howeler, R.H. (Ed.) Cassava breeding, agronomy and utilization research in Asia. CIAT, USA.

Bandaranayake, W. M. E. K., Wickramarachchi, W. A. R. T., Wickramasinghe, H. A. M., Rajapakshe, R. G. A. S and Dissanayake, D. M. K. K (2014). Molecular detection and characterization of begomoviruses associated with cucurbitaceae vegetables in Sri Lanka. Journal of Natural Science Foundation Sri Lanka 42, 239-245.

De Bruyn, A., Villemot, J., Lefeuvre, P., Villar, E., Hoareau, M., Harimalala, M., Abdoul-Karime, A.L., Abdou-Chakour, C., Reynaud, B., Harkins, G.W., Varsani, A., Martin, D.P and Lett, J.M (2012). East African cassava mosaic-like viruses from Africa to Indian ocean islands: molecular diversity, evolutionary history and geographical dissemination of a bipartite begomovirus. BMC Evolutionary Biology 12, 228.

Deng, D., Mcgrath, P.F and Harrison, B. D (1994). Detection and differentiation of whitefly-transmitted geminiviruses in plants and vector insects by the polymerase chain reaction with degenerate primers. Annals of Applied Biology 125, 327-336.

Doyle, J. J and Doyle, J. L (1987). A rapid DNA isolation procedure for small quantities of fresh leaf tissue. Phytochemical Bulletin 19, 11-15.

Fang, Y and Ramasamy, R. P (2015). Current and prospective methods for plant disease detection. Biosensors $5,537-561$.

Fernandes, A. M., Gazola, B., Nunes, J. G., Garcia, E. L and Leonel, M (2017). Yield and nutritional requirements of cassava in response to potassium fertilizer in the second cycle. Journal of Plant Nutrition 40, 2785-2796.
Graziosi, I., Minato, N., Alvarez, E., Ngo, D. T., Hoat, T. X., Aye, T. M., Pardo, J. M., Wongtiem, P. and Wyckhuys, K. A (2016), Emerging pests and diseases of South-east Asian cassava: a comprehensive evaluation of geographic priorities, management options and research needs. Pest Management Science 72, 1071-1089.

Harischandra, S. N., de Silva, K. K. N., Kahandawela, J. B. D. S and Wickramasingha, C. D (2005). Performance of three high yielding cassava (Manihot esculenta Crantz) varieties. Annals of the Sri Lanka Department of Agriculture 7, 353-356.

Huang, J. F., Jiang, T and Zhou, X. P (2006). Molecular characterization of begomoviruses infecting Ludwigia hyssopifolia. Journal of Plant Pathology 88, 81- 6.

Jesús Navas-Castillo, Elvira Fiallo-Olivé, Sonia SánchezCampos (2011). Emerging Virus Diseases Transmitted by Whiteflies. Annual Review of Phytopathology 49, 219-248.

Latif, S and Müller, J (2015) Potential of cassava leaves in human nutrition: a review. Trends in Food Science \& Technology 44 (2), 147-158.

Legg, J.P., Abele, S., Obiero, H., Jeremiah, S., Bigirimana, S and Ntawuruhunga, P (2005) The cassava mosaic virus disease pandemic and its impact on people's livelihoods in East and Central Africa, Phytopathology 95, 129-130.

Madalla, N., Agbo, N. W and Jauncey K (2016). Evaluation of ground - sundried cassava leaf meal as protein source for Nile Tilapia Oreochromis niloticus (L) Juvenile's Diet. Tanzania Journal of Agricultural Sciences 15 (1), 1-12.

Maruthi, M. N., Whitfield, E. C., Otti, G., Tumwegamire, S., Kanju, E., Legg, J. P., Mkamilo, G., Kawuki, R., Benesi, I., Zacarias, A., Munga, T., Mwatuni, F and Mbugua, E (2019). A method for generating virus-free cassava plants to combat viral disease epidemics in Africa. Physiological and Molecular Plant Pathology 105, 77-87.

Minato, N., Sok, S., Chen, S., Delaquis, E., Phirun, I., Le, V. X., Burra, D. D., Newby, J. C., Wyckhuys, K. A. G and de Haan, S (2019). Surveillance for Sri Lankan cassava mosaic virus (SLCMV) in Cambodia and Vietnam one year after its initial detection in a single plantation in 2015. PLoS ONE 14 (2), e0212780.

Ng, W. K., and Wee, K. L (1989). The nutritive value of cassava leaf meal in pelleted feed for Nile tilapia. Aquaculture 83, 45-58.

Ogbe, F. O., Atiri, G. I., Dixon, A.G.O and Thottappilly, G (2003). Symptom severity of cassava mosaic disease in relation to concentration of African cassava mosaic virus in different cassava genotypes. Plant Pathology 52, 84-91.

Prasangika, H. S. M., Salim, N and Razak, M. M (2008). Evaluation of susceptibility of cassava germplasm to cassava moisaic disease. Journal of the National Science Foundation of Sri Lanka, 36 (1), 99-102. 
Ravindran, V. 1993. Cassava leaves as animal feed: potential and limitations. Journal of the Science of Food and Agriculture 61: 141-150.

Salim, N and Bandumala, S. H (2001). Characterization of a geminivirus that infects cassava in Sri Lanka. Vidyodaya Journal of Science 10, 151-165.

Samarakoon, S. A. M. C., Balasuriya, A., Rajapaksha, R. G. A. S and Wickramarachchi, W. A. R. T (2012). Molecular detection and partial characterization of Tomato Leaf Curl Virus in Sri Lanka. Pakistan Journal of Biological Sciences 15 (18), 863-870.

Saunders, N., Salim, N., Mali, V. R, Malathi, V. G., Markham, P. G and Stanley, J (2002). Characterization of Sri
Lankan cassava mosaic virus: evidence for acquisition of a DNA B component by a monopartite begomovirus. Virology 29 (1), 63-74.

Santhi, R and Selvakumari, G (2000). Use of organic sources of nutrients in crop production, pp.87-101. In: Kannaiyan, E (Ed.) Theme papers on integrated nutrient management. Published by Tamil Nadu Agric. Univ. Tamil Nadu Dept. Agriculture.

Thresh, J. M and Cooter, R. J (2005). Strategies for controlling cassava mosaic virus disease in Africa. Plant Pathology 54,587-614. 